\title{
The Diabetes Educator
}

\section{Prevalence and Associated Risk Factors of Diabetes in the African Immigrant Population of Sacramento County, California}

\begin{tabular}{|r|l|}
\hline Journal: & The Diabetes Educator \\
\hline Manuscript ID & Draft \\
\hline Manuscript Type: & Original Research \\
\hline Keywords: & $\begin{array}{l}\text { diabetes, prevalence, risk factors, African immigrant population, } \\
\text { Sacramento County, California }\end{array}$ \\
\hline
\end{tabular}

\section{SCHOLARONE Manuscripts}


Table 1. Socio-demographic and clinical characteristics of study participants $(\mathrm{n}=126)$

\begin{tabular}{|c|c|c|c|c|}
\hline Variables & Total N (\%) & Males N (\%) & Females N (\%) & p-value* \\
\hline \multicolumn{5}{|l|}{ Age Group } \\
\hline $21-35$ years & $29(23.0)$ & $12(24.00)$ & $17(22.37)$ & \\
\hline $36-60$ years & $75(59.5)$ & $30(60.00)$ & $45(59.21)$ & \\
\hline 61 years and above & $22(17.5)$ & $8(16.00)$ & $14(18.42)$ & .93 \\
\hline \multicolumn{5}{|l|}{ Gender } \\
\hline Male & $50(39.7)$ & & & \\
\hline female & $76(60.3)$ & & & \\
\hline \multicolumn{5}{|l|}{ Country of Birth } \\
\hline Democratic Republic of Congo & $5(4.0)$ & $2(40.0)$ & $3(60.0)$ & \\
\hline Eritrea & $5(4.0)$ & $3(60.0)$ & $2(40.0)$ & \\
\hline Ethiopia & $16(12.7)$ & $10(62.5)$ & $6(37.5)$ & \\
\hline Gambia & $1(.8)$ & $1(100.0)$ & $0(0.0)$ & \\
\hline Ghana & $12(9.5)$ & $6(50.0)$ & $6(50.0)$ & \\
\hline Kenya & $23(18.3)$ & $7(30.4)$ & $16(69.6)$ & \\
\hline Liberia & $13(10.3)$ & $6(46.2)$ & $7(53.8)$ & \\
\hline Nigeria & $11(8.7)$ & $3(27.3)$ & $8(72.7)$ & \\
\hline Sierra Leone & $17(13.5)$ & $6(35.3)$ & $11(64.7)$ & \\
\hline South Africa & $4(3.2)$ & $1(25.0)$ & $3(75.0)$ & \\
\hline Uganda & $14(11.0)$ & $3(21.4)$ & $11(78.6)$ & \\
\hline Zimbabwe & $4.0(5)$ & $40.0(2)$ & $60.0(3)$ & .48 \\
\hline & & 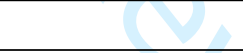 & & \\
\hline \multicolumn{5}{|l|}{ Length of stay in U.S. } \\
\hline$<5$ years & $23(18.2)$ & $6(12.0)$ & $17(22.4)$ & \\
\hline $5-10$ years & $32(25.4)$ & $13(26.0)$ & $19(25.0)$ & \\
\hline $11-15$ years & $20(15.9)$ & $11(22.0)$ & $9(11.8)$ & \\
\hline$\geq 16$ years & $51(40.5)$ & $20(40.0)$ & $31(40.8)$ & .28 \\
\hline \multicolumn{5}{|l|}{ Education status } \\
\hline Less than high school & $10(7.9)$ & $0(0.0)$ & $10(100.0)$ & \\
\hline High School & $23(18.3)$ & $8(34.8)$ & $15(65.2)$ & \\
\hline College Level & $93(73.8)$ & $42(84.00)$ & $51(67.1)$ & .019 \\
\hline \multicolumn{5}{|l|}{ Marital status } \\
\hline Single & $31(24.6)$ & $8(25.8)$ & $23(74.2)$ & \\
\hline Married & $75(59.5)$ & $37(49.3)$ & $38(50.7)$ & \\
\hline Divorced & $7(5.6)$ & $4(57.1)$ & $3(42.9)$ & \\
\hline Separated & $1(.8)$ & $0(0.0)$ & $1(100.0)$ & \\
\hline Widowed & $12(9.5)$ & $1(8.3)$ & $11(91.7)$ & .018 \\
\hline Employment status & & & & \\
\hline
\end{tabular}




\begin{tabular}{|c|c|c|c|c|}
\hline Part-Time & $18(14.3)$ & $6(33.3)$ & $12(66.70$ & \\
\hline Full-Time & $76(60.3)$ & $37(48.7)$ & $39(51.3)$ & \\
\hline Retired & $6(4.8)$ & $3(50.0)$ & $3(50.0)$ & \\
\hline Self-employed & $3(2.4)$ & $1(33.3)$ & $2(66.7)$ & \\
\hline Homemaker & $4(3.2)$ & $0(0.0)$ & $4(100.0)$ & \\
\hline Do Not Work & $14(11.1)$ & $2(14.3)$ & $12(85.7)$ & \\
\hline Student & $5(4.0)$ & $1(20.0)$ & $4(80.0)$ & .019 \\
\hline \multicolumn{5}{|l|}{ Health insurance status } \\
\hline Via employer & $64(50.8)$ & $30(46.9)$ & $34(53.1)$ & \\
\hline $\begin{array}{r}\text { Via spouse or partner's } \\
\text { employer }\end{array}$ & $12(9.5)$ & $5(41.7)$ & $7(58.3)$ & \\
\hline $\begin{array}{r}\text { Medi-Cal (California's } \\
\text { Medicaid) }\end{array}$ & $44(34.9)$ & $12(27.3)$ & $32(72.7)$ & \\
\hline No insurance & $6(4.8)$ & $3(50.0)$ & $3(50.0)$ & .21 \\
\hline & 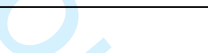 & & & \\
\hline \multicolumn{5}{|l|}{$\begin{array}{l}\text { Have been told have Pre- } \\
\text { diabetes }\end{array}$} \\
\hline 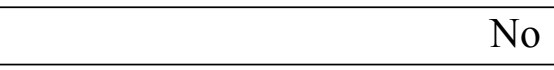 & $100(79.4)$ & $41(41.0)$ & $59(59.0)$ & \\
\hline Yes & $24(19.1)$ & $9(37.5)$ & $15(62.5)$ & \\
\hline Don't know & $2(1.6)$ & $0(0.0)$ & $2(100.0)$ & .49 \\
\hline & & 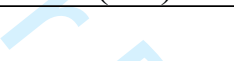 & & \\
\hline \multicolumn{5}{|l|}{ Have been told have DM } \\
\hline (1) & $101(80.2)$ & $40(39.6)$ & $61(60.4)$ & \\
\hline \multirow[t]{2}{*}{ Yes } & $25(19.8)$ & $10(40.0)$ & $15(60.0)$ & .97 \\
\hline & & $x^{2}$ & $e^{2}$ & \\
\hline \multicolumn{5}{|l|}{ Taking medication(s) for DM } \\
\hline Insulin & $5(4.0)$ & $5(100.0)$ & $0(0.0)$ & \\
\hline Oral Medication(s) & $20(15.9)$ & $5(25.0)$ & $15(75.0)$ & .002 \\
\hline \multicolumn{5}{|l|}{$\begin{array}{l}\text { Have been told have } \\
\text { Hypertension (High Blood } \\
\text { Pressure) }\end{array}$} \\
\hline No & $94(74.6)$ & $40(42.6)$ & $54(57.4)$ & \\
\hline Yes & $32(25.4)$ & $10(31.3)$ & $22(68.8)$ & .26 \\
\hline \multicolumn{5}{|l|}{$\begin{array}{l}\text { Have been told have heart } \\
\text { disease }\end{array}$} \\
\hline No & $123(97.6)$ & $49(39.8)$ & $74(60.2)$ & \\
\hline Yes & $3(2.4)$ & $1(33.3)$ & $2(66.7)$ & .82 \\
\hline \multicolumn{5}{|l|}{$\begin{array}{l}\text { Have been told have high } \\
\text { Blood Cholesterol }\end{array}$} \\
\hline No & $83(65.9)$ & $32(38.6)$ & $51(61.4)$ & \\
\hline
\end{tabular}




\begin{tabular}{|c|c|c|c|c|}
\hline Yes & $43(34.1)$ & $18(41.9)$ & $25(58.1)$ & .72 \\
\hline \multicolumn{5}{|l|}{$\begin{array}{l}\text { Have family member(s) with } \\
\text { DM }\end{array}$} \\
\hline No & $72(57.1)$ & $29(40.3)$ & $43(59.7)$ & \\
\hline Yes & $54(42.9)$ & $21(38.9)$ & $33(61.1)$ & .87 \\
\hline \multicolumn{5}{|l|}{ Last regular medical check-up } \\
\hline Within the past year & 94 (74.6) & $31(33.0)$ & $63(67.0)$ & \\
\hline Within the past 2 years & $17(13.5)$ & $8(16.0)$ & $9(11.8)$ & \\
\hline Within the past $3-5$ years & $4(3.2)$ & $4(8.0)$ & $0(0.0)$ & \\
\hline More than 5 years ago & $7(5.6)$ & $6(12.0)$ & $1(1.3)$ & \\
\hline \multicolumn{5}{|l|}{ Don't Know } \\
\hline $\begin{array}{r}\text { Never had a regular medical } \\
\text { check-up }\end{array}$ & $4(3.2)$ & $1(2.0)$ & $3(3.9)$ & .005 \\
\hline & 8 & & & \\
\hline \multicolumn{5}{|l|}{$\begin{array}{l}\text { Days per week of moderate } \\
\text { physical activities }\end{array}$} \\
\hline 0 day & $10(7.9)$ & $3(6.0)$ & $7(9.2)$ & \\
\hline $1-2$ days & $53(42.1)$ & $20(40.0)$ & $33(43.4)$ & \\
\hline $3-4$ days & $48(38.1)$ & $20(40.0)$ & $28(36.8)$ & \\
\hline $5-7$ days & $15(11.9)$ & $7(14.0)$ & $8(10.5)$ & .83 \\
\hline & & 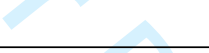 & & \\
\hline \multicolumn{5}{|l|}{$\begin{array}{l}\text { Days per week of vigorous } \\
\text { physical activities }\end{array}$} \\
\hline 0 day & $49(38.9)$ & $16(32.0)$ & $33(43.4)$ & \\
\hline $1-2$ days & $52(41.3)$ & $22(44.0)$ & $30(39.5)$ & \\
\hline $3-4$ days & $17(13.5)$ & $10(20.0)$ & $7(9.2)$ & \\
\hline $5-7$ days & $8(6.3)$ & $2(4.0)$ & $6(7.9)$ & .21 \\
\hline \multicolumn{5}{|l|}{ Current/previous Smoking } \\
\hline Yes & $8(6.3)$ & $7(14.0)$ & $1(1.3)$ & \\
\hline No & $118(93.7)$ & $43(86.0)$ & 75 (98.7) & .004 \\
\hline \multicolumn{5}{|l|}{$\begin{array}{l}\text { How careful selecting healthier } \\
\text { diet }\end{array}$} \\
\hline $\begin{array}{r}\text { Very careful / somewhat } \\
\text { careful }\end{array}$ & $74(58.7)$ & $30(60.0)$ & $44(57.9)$ & \\
\hline $\begin{array}{r}\text { Slightly careful / not at all } \\
\text { careful }\end{array}$ & $52(41.3)$ & $20(40.0)$ & $32(42.1)$ & .81 \\
\hline
\end{tabular}

*p-value for Pearson's chi-square test. DM= Diabetes Mellitus; Moderate Physical activity refers to activity that may make a person breathe slightly harder than when he/she is sitting, like fast walking, gardening, or mowing with a push mower; Vigorous activity refers to activity that causes sweating and hard breathing, like running or biking fast or uphill. 
Table 2. Socio-demographic and clinical characteristics of study participants $(n=126)$

\begin{tabular}{|l|c|c|c|c|}
\hline Variables & $\begin{array}{c}\text { Total } \\
\text { Mean (SD) }\end{array}$ & $\begin{array}{c}\text { Males } \\
\text { Mean (SD) }\end{array}$ & $\begin{array}{c}\text { Females } \\
\text { Mean (SD) }\end{array}$ & p-value* \\
\hline Age & $46.8(14.6)$ & $45.2(13.5)$ & $47.9(15.2)$ & .31 \\
\hline Age at immigration to U.S. & $33.2(15.6)$ & $30.5(11.5)$ & $34.9(17.6)$ & .12 \\
\hline Length of stay in U.S. (in years) & $13.6(9.6)$ & $14.7(10.2)$ & $12.9(9.1)$ & .31 \\
\hline Systolic BP (mmHg) & $131(16.6)$ & $133(15.5)$ & $129(17.3)$ & .14 \\
\hline Diastolic BP (mmHg) & $83(10.9)$ & $83(11.9)$ & $83(10.3)$ & .79 \\
\hline Weight $(\mathrm{kg})$ & $78.9(17.0)$ & $81.4(17.6)$ & $77.2(16.5)$ & .17 \\
\hline Height $(m e t e r)$ & $1.65(.09)$ & $1.7(.08)$ & $1.6(.07)$ & $<.0001$ \\
\hline BMI $\left(\mathrm{kg} / \mathrm{m}^{2}\right)$ & $28.8(5.8)$ & $27.5(5.5)$ & $29.7(5.8)$ & .041 \\
\hline $\mathrm{HbA}_{1} \mathrm{c}$ & $5.9(1.01)$ & $6.1(1.2)$ & $5.8(.84)$ & .21 \\
\hline
\end{tabular}

*p-value for t-test comparisons. Systolic $\mathrm{BP}=$ Systolic Blood Pressure (in $\mathrm{mmHg}$ ); Diastolic $\mathrm{PB}=$ Diastolic Blood Pressure (in $\mathrm{mmHg}$ ) 
Table 3. Distribution of Blood Pressure, $\mathrm{BMI}$, and $\mathrm{HbA}_{1} \mathrm{c}$ by gender

\begin{tabular}{|c|c|c|c|c|}
\hline Variable & $\begin{array}{c}\text { Total } \\
\text { N (\%) }\end{array}$ & $\begin{array}{l}\text { Males } \\
\text { N (\%) }\end{array}$ & $\begin{array}{c}\text { Females } \\
\mathrm{N}(\%)\end{array}$ & p-value* \\
\hline Systolic BP $\geq 140$ & $32(25.4)$ & $15(30.0)$ & $17(22.4)$ & .33 \\
\hline Diastolic BP $\geq 90$ & $28(20.6)$ & $13(26.0)$ & $15(19.7)$ & .41 \\
\hline \multicolumn{5}{|l|}{ BMI $\left(\mathrm{kg} / \mathrm{m}^{2}\right)$} \\
\hline$<25$ & $33(26.2)$ & $16(32.0)$ & $17(22.4)$ & \\
\hline $25.0-29.9$ & $50(39.7)$ & $24(48.0)$ & $26(34.2)$ & \\
\hline$\geq 30$ & $43(34.1)$ & $10(20.0)$ & $33(43.4)$ & 0.02 \\
\hline \multicolumn{5}{|l|}{$\mathrm{HbA}_{1} \mathrm{c}(\%)$} \\
\hline Normal $(\leq 5.6)$ & $60(47.6)$ & $20(40.0)$ & $40(52.6)$ & \\
\hline Pre-diabetes (5.7-6.4) & $36(28.6)$ & $17(34.0)$ & $19(25.0)$ & \\
\hline Diabetes $(\geq 6.5)$ & $30(23.8)$ & $13(26.0)$ & $17(22.4)$ & 0.62 \\
\hline
\end{tabular}

*p-value for Pearson's chi-square test. $\mathrm{SBP}=$ Systolic Blood Pressure (in mmHg), DPB=Diastolic Blood Pressure (in $\mathrm{mmHg}$ );

$\mathrm{HbA}_{1} \mathrm{c}$ : Normal, when $\mathrm{HbA}_{1} \mathrm{c} \leq 5.6 \%$; pre-diabetes, when $\mathrm{HbA}_{1} \mathrm{c}$ is between 5.7 - 6.4; diabetes, when $\mathrm{HbA}_{1} \mathrm{c} \geq 6.5 \%$ 
Table 4. Prevalence of diagnosed and undiagnosed pre-diabetes and diabetes

\begin{tabular}{|l|c|c|c|}
\hline \multicolumn{1}{|c|}{ Variable } & $\begin{array}{c}\text { Total cases } \\
\text { N (\%) }\end{array}$ & $\begin{array}{c}\text { Previously diagnosed cases } \\
\text { N (\%) }\end{array}$ & $\begin{array}{c}\text { New cases } \\
\text { N (\%) }\end{array}$ \\
\hline Pre-diabetes & $36(28.6)$ & $24(19.1)$ & $12(9.5)$ \\
\hline Diabetes & $32(25.4)$ & $25(19.8)$ & $7(5.6)$ \\
\hline
\end{tabular}

Pre-diabetes is defined as diagnosis by a healthcare provider and/or $\mathrm{HbA}_{1} \mathrm{c}$ of $5.7-6.4 \%$

Diabetes is defined as diagnosis by a healthcare provider and/or on antidiabetic medications and/or $\mathrm{HbA}_{1} \mathrm{c} \geq 6.5 \%$ 
Table 5. Association between socio-demographic and clinical characteristics of study participants and Glycemic Level.

\begin{tabular}{|c|c|c|c|c|c|}
\hline \multirow[t]{2}{*}{ Variables } & \multicolumn{3}{|c|}{ Glycemic Level } & \multirow{2}{*}{$\begin{array}{c}\text { Total } \\
(\mathrm{N}=126)\end{array}$} & \multirow[t]{2}{*}{ p-value } \\
\hline & $\begin{array}{c}\text { Normal } \\
(\mathrm{n}=60) \\
{\left[\mathrm{HbA}_{1} \mathrm{c}<\right.} \\
5.7]\end{array}$ & $\begin{array}{c}\text { Pre-diabetes } \\
(\mathrm{n}=36) \\
{\left[\mathrm{HbA}_{1} \mathrm{c} \text { of }\right.} \\
5.7-6.4]\end{array}$ & $\begin{array}{c}\text { Diabetes } \\
(\mathrm{n}=30) \\
{\left[\mathrm{HbA}_{1} \mathrm{c}\right.} \\
\geq 6.5 \%]\end{array}$ & & \\
\hline \multicolumn{6}{|l|}{ Age Group } \\
\hline $21-35$ years & $17(28.3)$ & $7(19.4)$ & $5(16.7)$ & $29(23.0)$ & \\
\hline $36-60$ years & $37(61.7)$ & $23(63.9)$ & $15(50.0)$ & $75(59.5)$ & \\
\hline 61 years and above & $6(10.0)$ & $6(16.7)$ & $10(33.3)$ & $22(17.5)$ & 0.08 \\
\hline \multicolumn{6}{|l|}{ Gender } \\
\hline Male & $20(33.3)$ & $17(47.2)$ & $13(43.3)$ & $50(39.7)$ & \\
\hline female & $40(66.7)$ & $19(52.8)$ & $17(56.7)$ & $76(60.3)$ & 0.36 \\
\hline & 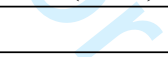 & & & & \\
\hline \multicolumn{6}{|l|}{ Country of Birth } \\
\hline Democratic Republic of Congo & $4(6.7)$ & $1(2.8)$ & $0(0)$ & $5(4.0)$ & \\
\hline Eritrea & $0(0)$ & $3(8.3)$ & $2(6.7)$ & $5(4.0)$ & \\
\hline Ethiopia & $9(15.0)$ & $6(16.7)$ & $1(3.3)$ & $16(12.7)$ & \\
\hline Gambia & $0(0)$ & $1(2.8)$ & $0(0)$ & $1(.8)$ & \\
\hline Ghana & $6(10.0)$ & $4(11.1)$ & $2(6.7)$ & $12(9.5)$ & \\
\hline Kenya & $12(20.0)$ & $4(11.1)$ & $7(23.3)$ & $23(18.3)$ & \\
\hline Liberia & $6(10.0)$ & $3(8.3)$ & $4(13.3)$ & $13(10.3)$ & \\
\hline Nigeria & $6(10.0)$ & $3(8.3)$ & $2(6.7)$ & $11(8.7)$ & \\
\hline Sierra Leone & $6(10.0)$ & $6(16.7)$ & $5(16.7)$ & $17(13.5)$ & \\
\hline South Africa & $2(3.3)$ & $1(2.8)$ & $1(3.3)$ & $4(3.2)$ & \\
\hline Uganda & $9(15.0)$ & $2(5.6)$ & $3(10.0)$ & $14(11.0)$ & \\
\hline Zimbabwe & $0(0)$ & $2(5.5)$ & $3(10.0)$ & $5(4)$ & .39 \\
\hline \multicolumn{6}{|l|}{ Length of stay in U.S. } \\
\hline$<5$ years & $11(18.3)$ & $7(19.4)$ & $5(16.7)$ & $23(18.3)$ & \\
\hline $5-10$ years & $14(23.3)$ & $7(19.4)$ & $11(36.6)$ & $32(25.4)$ & \\
\hline $11-15$ years & $11(18.3)$ & $5(14.0)$ & $4(13.3)$ & $20(15.9)$ & \\
\hline$\geq 16$ years & $24(40.0)$ & $17(47.2)$ & $10(33.3)$ & $51(40.4)$ & 0.76 \\
\hline \multicolumn{6}{|l|}{ Education status } \\
\hline Less than high school & $3(5.0)$ & $4(11.1)$ & $3(10.0)$ & $10(7.9)$ & \\
\hline High School & $7(11.7)$ & $9(25.0)$ & $7(23.3)$ & $23(18.3)$ & \\
\hline College Level & $50(83.3)$ & $23(63.9)$ & $20(66.7)$ & $93(73.8)$ & 0.27 \\
\hline \multicolumn{6}{|l|}{ Marital status } \\
\hline Single & $22(36.7)$ & $3(8.3)$ & $6(20.0)$ & $31(24.6)$ & \\
\hline Married & $34(56.7)$ & $28(77.8)$ & $13(43.3)$ & $75(59.5)$ & \\
\hline Divorced & $1(1.6)$ & $1(2.8)$ & $5(16.7)$ & $7(5.6)$ & \\
\hline Separated & $0(0.0)$ & $0(0.0)$ & $1(3.3)$ & $1(.8)$ & \\
\hline
\end{tabular}




\begin{tabular}{|c|c|c|c|c|c|}
\hline Widowed & $3(5.0)$ & $4(11.1)$ & $5(16.7)$ & $12(9.5)$ & .001 \\
\hline \multicolumn{6}{|l|}{ Employment status } \\
\hline Part-Time & $10(16.7)$ & $3(8.3)$ & $5(16.7)$ & $18(14.3)$ & \\
\hline Full-Time & $37(61.6)$ & $23(63.9)$ & $16(53.3)$ & $76(60.3)$ & \\
\hline Retired & $1(1.7)$ & $1(2.8)$ & $4(13.3)$ & $6(4.8)$ & \\
\hline Self-employed & $2(3.3)$ & $1(2.8)$ & $0(0.0)$ & $3(2.4)$ & \\
\hline Homemaker & $2(3.3)$ & $1(2.8)$ & $1(3.3)$ & $4(3.2)$ & \\
\hline Do Not Work & $4(6.7)$ & $7(19.4)$ & $3(10.0)$ & $14(11.1)$ & \\
\hline Student & $4(6.7)$ & $0(0.0)$ & $1(3.3)$ & $5(4.0)$ & 0.26 \\
\hline \multicolumn{6}{|l|}{$\begin{array}{l}\text { Have been told have } \\
\text { Hypertension (High Blood } \\
\text { Pressure) }\end{array}$} \\
\hline 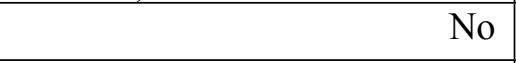 & $50(83.3)$ & $28(77.8)$ & $16(53.3)$ & $94(74.6)$ & \\
\hline Yes & $10(16.7)$ & $8(22.2)$ & $14(46.7)$ & $32(25.4)$ & 0.008 \\
\hline & 20 & & & & \\
\hline \multicolumn{6}{|l|}{$\begin{array}{l}\text { Have been told have high } \\
\text { Blood Cholesterol }\end{array}$} \\
\hline 2 & $49(81.7)$ & $28(77.8)$ & $6(20.0)$ & $83(65.9)$ & \\
\hline Yes & $11(18.3)$ & $8(22.2)$ & $24(80.0)$ & $43(34.1)$ & $\begin{array}{c}<0.000 \\
1\end{array}$ \\
\hline \multicolumn{6}{|l|}{$\begin{array}{l}\text { Have family member(s) with } \\
\text { DM }\end{array}$} \\
\hline No & $33(55.0)$ & $23(63.9)$ & $16(53.3)$ & $72(57.1)$ & \\
\hline Yes & $27(45.0)$ & $13(36.1)$ & $14(46.7)$ & $54(42.9)$ & 0.62 \\
\hline & & & +2 & & \\
\hline \multicolumn{6}{|l|}{ Last regular medical check-up } \\
\hline Within the past year & $46(76.7)$ & $23(63.9)$ & $25(83.3)$ & $94(74.6)$ & \\
\hline Within the past 2 years & $9(15.0)$ & $7(19.4)$ & $1(3.3)$ & $17(13.5)$ & \\
\hline Within the past 3-5 years & $2(3.3)$ & $2(5.6)$ & $0(0.0)$ & $4(3.2)$ & \\
\hline More than 5 years ago & $3(5.0)$ & $1(2.8)$ & $3(10.0)$ & $7(5.6)$ & \\
\hline $\begin{array}{r}\text { Never had a regular medical } \\
\text { check-up }\end{array}$ & $0(0.0)$ & $3(8.3)$ & $1(3.3)$ & & 0.14 \\
\hline \multicolumn{6}{|l|}{$\begin{array}{l}\text { Days per week of moderate } \\
\text { physical activities }\end{array}$} \\
\hline 0 day & $4(6.7)$ & $6(16.7)$ & $0(0.0)$ & $10(7.9)$ & \\
\hline $1-2$ days & $26(43.3)$ & $12(33.3)$ & $15(50.0)$ & $53(42.1)$ & \\
\hline $3-4$ days & $19(31.7)$ & $14(38.9)$ & $15(50.0)$ & $48(38.1)$ & \\
\hline $5-7$ days & $11(18.3)$ & $4(11.1)$ & $0(0.0)$ & $15(11.9)$ & 0.02 \\
\hline \multicolumn{6}{|l|}{$\begin{array}{l}\text { Days per week of vigorous } \\
\text { physical activities }\end{array}$} \\
\hline 0 day & $25(41.7)$ & $12(33.3)$ & $12(40)$ & $49(38.9)$ & \\
\hline $1-2$ days & $20(33.3)$ & $16(44.4)$ & $16(53.3)$ & $52(41.3)$ & \\
\hline
\end{tabular}




\begin{tabular}{|r|c|c|c|c|c|}
$3-4$ days & $10(16.7)$ & $5(13.9)$ & $2(6.7)$ & $17(13.5)$ & \\
\hline $5-7$ days & $5(8.33)$ & $3(8.33)$ & $0(0.0)$ & $8(6.3)$ & 0.37 \\
\hline Yurrent/previous Smoking & & & & & \\
\hline No & $2(3.33)$ & $4(11.1)$ & $2(6.7)$ & $8(6.3)$ & \\
\hline $\begin{array}{r}\text { How careful selecting healthier } \\
\text { diet }\end{array}$ & & $32(88.9)$ & $28(93.3)$ & $118(93.7)$ & 0.32 \\
\hline $\begin{array}{r}\text { Very careful / somewhat } \\
\text { careful }\end{array}$ & $35(58.3)$ & $22(61.1)$ & $17(56.7)$ & $74(58.7)$ & \\
\hline $\begin{array}{r}\text { Slightly careful / not at all } \\
\text { careful }\end{array}$ & $25(41.7)$ & $14(28.6)$ & $13(23.8)$ & $52(41.3)$ & 0.93 \\
\hline
\end{tabular}

\section{Chi-square: Pearson's Chi-square.}


Table 6. Treatment and control status among diabetic participants

\begin{tabular}{|c|c|c|c|c|}
\hline \multirow{2}{*}{$\begin{array}{l}\text { Demographic } \\
\text { variables }\end{array}$} & \multirow{2}{*}{$\begin{array}{c}\text { Total diabetics } \\
\mathrm{N}\end{array}$} & \multirow{2}{*}{$\begin{array}{l}\text { On treatment } \\
\qquad \mathrm{N}(\%)\end{array}$} & \multicolumn{2}{|c|}{ Glycemic control } \\
\hline & & & $\begin{array}{c}\mathrm{HbA}_{1} \mathrm{c}<7(\text { Good } \\
\text { control) } \\
\mathrm{N}(\%)\end{array}$ & $\begin{array}{c}\mathrm{HbA}_{1} \mathrm{c}>7 \\
\text { (Poor control) N (\%) }\end{array}$ \\
\hline Total & 25 & $25(100.0)$ & $5(20.0)$ & $20(80.0)$ \\
\hline \multicolumn{5}{|l|}{ Gender } \\
\hline Male & 10 & $10(40.0)$ & $1(10.0)$ & $9(90.0)$ \\
\hline Female & 15 & $15(60.0)$ & $4(26.7)$ & $11(73.3)$ \\
\hline
\end{tabular}

Good glycemic control is defined as $\mathrm{HbA}_{1} \mathrm{c}<7 \%$ 
Diabetes is a chronic metabolic disease which emerged as a leading global health problem affecting approximately 422 million adults worldwide and characterized by high levels of glucose in the blood. ${ }^{1}$ Type 2 diabetes contributes up to $90 \%$ of all cases of diabetes. Because of their increasing risk of developing diabetes, the American Diabetes Association (ADA) recommends testing for diabetes and pre-diabetes among all individuals age 45 years and older. Similarly, testing is recommended among adults with $\mathrm{BMI} \geq 25 \mathrm{~kg} / \mathrm{m}^{2}$ who have additional risk factors including physical inactivity, a first-degree relative with diabetes, being a member of a high-risk ethnic population, and having a history of gestational diabetes, polycystic ovary syndrome, or one of several clinical risk factors such; as hypertension, high-density lipoprotein cholesterol (HDL-C) $<35 \mathrm{mg} / \mathrm{dl}$, triglycerides $>250 \mathrm{mg} / \mathrm{dl}$, Hemoglobin $\mathrm{A}_{\mathrm{lc}}\left(\mathrm{HbA}_{\mathrm{lc}}\right) \geq 5.7 \%$, impaired glucose tolerance (IGT), impaired fasting glucose (IFG), or cardiovascular disease. ${ }^{2}$

California has the greatest number of people in the U.S. who are newly diagnosed with diabetes. ${ }^{3}$ In 2010, about 11.4 million (41\%) adults in California had pre-diabetes, a condition that often precedes type 2 diabetes. ${ }^{4,5}$ Ethnic minority populations in California have the highest risk and prevalence of diabetes. ${ }^{3}$ African immigrants in particular are a rapidly growing sub-group with cultural behaviors and lifestyle characteristics that can increase the likelihood of developing diabetes. Findings from a previous study conducted by Kindarara et $\mathrm{al}^{6}$ with 10 African immigrant adults with type 2 diabetes in the Sacramento Area, California revealed barriers to diabetes self-management to be: being unaware of the disease, being unfamiliar with how to prevent the disease, and believing that it is only necessary to seek health care when ill. There are an estimated 1.6 million African immigrants in the U.S. ${ }^{7}$ However, their diabetes data are typically conflated with those of other members of the black or African-American population, with whom they share similar genetic characteristics such as skin color, ${ }^{8,9}$ though the diabetes-related problems faced by immigrants are unique. Data from the International Medicine Clinic at Seattle's Harborview Medical Center estimated that $60 \%$ of African 
immigrant patients have diabetes..$^{10}$ In addition, in Minneapolis and St. Paul, Minnesota, Liberian and Kenyan immigrants are even more likely to be diabetic than Somalis. ${ }^{11}$ A consultant in the Mayo Clinic's Division of Endocrinology stated that a growing number of Somali immigrants are developing type 2 diabetes as quickly as six months after their arrival in the U.S. ${ }^{12}$ and this phenomenon is attributed to a lack of exercise and a dramatic increase in fat and calorie consumption. ${ }^{13}$ There are increasing multi-pronged efforts toward preventing and controlling diabetes among ethnic minority populations in California and the U.S. in general, yet, diabetes risks and prevalence among the 158,953 African immigrants living in California ${ }^{7}$ remain unknown. Such knowledge is critical to the development and effective targeting of diabetes prevention and treatment efforts in the African immigrant population. Therefore, the present study aimed to assess the prevalence and associated risk factors of diabetes in the African immigrant population in Sacramento County, California.

\section{Socioecological Perspective of Pre-diabetes and Diabetes}

Prevention requires understanding the factors that influence ${ }^{14}$ diabetes. While much investigation on pre-diabetes and diabetes risk factors has focused on the individual-level factors such as socio-economic status (SES), cultural and psychosocial, ${ }^{15}$ a socioecological perspective recognizes the influence of social and environmental factors that increase the vulnerability of the African immigrant population to diabetes.

Because our interest is to understand the risk factors that influence diabetes and intervene in diabetes prevention and treatment, the present study adopted the socioecological perspective in order to expand the narrow focus on individual-level factors to include a broader consideration of the multiple contexts or organizational levels ${ }^{15}$ within which African immigrants are embedded. The prevalence of pre-diabetes and diabetes among immigrant populations is a complex issue, with significant multiple levels of influences from the integration of individual-level factors and multilevel factors such as 
family/social networks, health care settings/practices, and the physical and social environment, and local, state and national policies. ${ }^{15}$ For example, dietary behaviors such as processed and red meat consumption may be impacted by an individual's physiological response to that diet, but also by family attitudes and beliefs, or the community's culture and public policies that affect the price of food. Expanding our understanding beyond individual-level risk factors is crucial to not only understand the social epidemiology of diabetes, but also to act across multiple levels of the socioecological approach at the same time, which is more likely to sustain prevention and treatment efforts over time.

\section{Methods}

\section{Study Design and Sample Size}

This study was based on a cross-sectional design which allowed for the collection of data from June to August 2018 to determine the prevalence of diabetes and its major risk factors among African immigrants. The number of eligible African immigrants who were approached was 150 . Out of these, 126 (response rate of $84.0 \%$ ) agreed to participate in this study. The convenience sample included participants aged 21 years and older who were residents of Sacramento County, California. The age range was based on the mean age of participants in a previous study conducted by the author (DMK) with African immigrant adults with type 2 diabetes in the Sacramento Area ${ }^{6}$ and reflects the ages (21 and older) recommended by the ADA for members of a high-risk ethnic population, such as AfricanAmerican population for pre-diabetes and diabetes screening. ${ }^{16}$

\section{Study Area}

There are an estimated 8,257 African immigrants in Sacramento County. ${ }^{17}$ According to the Community Health Status 2014 Report, diabetes prevalence has been increasing in California residents, especially in the Greater Sacramento region. ${ }^{18}$ In 2011, the prevalence of diabetes in Sacramento County was $9.2 \%$ compared to the remainder of California (8.4\%). ${ }^{18}$ In Sacramento County in 2011, African Americans, which includes African immigrants, had a higher diabetes prevalence (13.2\%) than 
Asian/Pacific Islanders (12.9\%), non-Hispanic whites (9.4\%), and Hispanics $(4.7 \%) .{ }^{18}$ Thus, this area was appropriate for this study to gain a greater understanding of the scope of the diabetes problem of the African immigrant population.

\section{Data Collection}

The California State University, Sacramento (CSUS) Institutional Review Board approved the study. Data were collected by the author (DMK). After signing an informed consent, a questionnaire was given to each participant to collect socio-demographic and clinical data which included age, gender, country of birth, age at immigration to U.S., length of stay in U.S., level of education, marital status, employment status, health insurance status. Information was also obtained on history of pre-diabetes and diabetes (whether a healthcare provider had told them they had pre-diabetes or diabetes), if diabetic, duration of diabetes and if on medication, type of medication. Additionally, information was collected on history of hypertension, heart disease, high blood cholesterol (whether a healthcare provider had told them they had any of the previous), gestational diabetes (for female participants only), whether they had family history of diabetes (how many family members), and when they had their last regular medical check-up. Information was also collected on whether they engaged in moderate physical activity; activity that may make a person breathe slightly harder than when he/she is sitting, like fast walking, gardening, or mowing with a push mower; or they engaged in vigorous physical activity that causes sweating and hard breathing, like running or biking fast or uphill. Information on smoking status and healthy eating habits were also collected.

\section{Anthropometric Measurements}

Upon completion of the questionnaire, anthropometric measurements were performed, including height and weight using standardized methods and calibrated instruments. Body weight (to the nearest $0.1 \mathrm{lbs}$ / $0.05 \mathrm{~kg}$ ) was measured using a calibrated health-o-meter ${ }^{\circledR}$ digital scale, while the participant was barefoot and wearing light clothing. Standing height was measured using a tape measure to the nearest 
0.25 of an inch with the participant standing barefoot on a flat floor with no carpeting next to a wall and eyes looking straight ahead. The Body Mass Index (BMI) was calculated as weight in kilograms divided by the square of height in meters. ${ }^{19}$ Two blood pressure measurements were taken at least 5 minutes apart from each participant after several minutes in a seated position; using a digital blood pressure monitor. The average of the two readings was used for analysis. Then, peripheral blood sample by finger puncture (fingerstick) was collected from each participant to estimate the $\mathrm{HbA}_{1 \mathrm{c}}$ value using A1C Now+ meter for diabetes care. Quality control testing was performed with each new shipment of A1C Now + meter to ensure that storage conditions had not affected the product. $\mathrm{HbA}_{1 \mathrm{c}}$, an indicator of three-month glycemic control, was used to test blood glucose concentration in order to identify individuals at high risk of developing diabetes or diagnose the disease. ${ }^{20}$ The ADA recommends $\mathrm{HbA}_{1 \mathrm{c}}$ as part of the pre-diabetes and diabetes diagnostic criteria. ${ }^{21} \mathrm{HbA}_{1 \mathrm{c}}$ is a simple, minimally invasive measure that will not require the participants to be in a fasted state. ${ }^{22}$

\section{Definition of Terms}

Overweight was defined as a BMI of $25.0-29.9 \mathrm{~kg} / \mathrm{m}^{2}$ and obesity was defined as a BMI of $\geq 30 \mathrm{~kg} / \mathrm{m}^{2}$. A participant was considered to be hypertensive if his/her current systolic blood pressure (SBP) was $\geq 140 \mathrm{mmHg}$ and/or diastolic blood pressure (DBP) was $\geq 90 \mathrm{mmHg}$ [Joint National Committee 8 (JNC8) Criteria]. ${ }^{23}$ Pre-diabetes was considered in participants with a previous diagnosis by a physician or other health professional or if participants had $\mathrm{HbA}_{1 \mathrm{c}}$ levels between $5.7 \%$ and $6.4 \%$ at the time of data collection. ${ }^{24}$ Diabetes was considered in participants with a previous diagnosis by a physician or other health professional and/or had been taking antihypoglycemic medication or participants had $\mathrm{HbA}_{1 \mathrm{c}}$ levels of $6.5 \%$ or greater ${ }^{24}$ at the time of data collection. Diabetes was considered controlled (good control of diabetes) if a participant with a previous diagnosis of diabetes by a physician or other 
health professional stated he/she was receiving treatment with antihypoglycemic medication and had a $\mathrm{HbA}_{1 \mathrm{c}}<7 \%$ at the time of data collection.

\section{Data Analysis}

Statistical analysis was performed using the Statistical Package for Social Sciences (SPSS, Inc., Chicago, IL, USA) version 24.0. Categorical variables were expressed as percentages. Means and standard deviations were calculated for continuous variables and the means were compared using the independent samples t-test. Pearson Chi-Square or Fisher exact was used to determine the relationship between socio-demographic and clinical factors and diabetes. Values of $p<0.05$ were considered statistically significant.

\section{Results}

\section{Socio-demographic and clinical characteristics}

Table 1 summarizes socio-demographic and clinical characteristics of study participants. Out of 126 participants aged between 22 and 90 years old (mean age of 46.8), there were $50(39.7 \%)$ men and $76(60.3 \%)$ women. Participants had lived in the U.S. between six months and 53 years $(\mathrm{mean}=13.6$, $\mathrm{SD}=9.6)$, mean age at immigration to the U.S. was 33.2 years $(\mathrm{SD}=15.6)$, and were native to 12 African countries: Democratic Republic of Congo (5 people); Eritrea (5); Ethiopia (16); Gambia (1); Ghana (12); Kenya (23); Liberia (13); Nigeria (11); Sierra Leone (17); South Africa (4); Uganda (14); and Zimbabwe (5).

Of the total number of participants, 75 (59.5\%) were married, $93(73.9 \%)$ had some college: Associate's Degree; Bachelor's Degree; or Master's Degree, 76 (60.3\%) reported full-time employment, $76(60.3 \%)$ had health insurance via employer or spouse/partner's employer. Twenty-four (19.1\%) had been told that they had pre-diabetes, $25(19.8 \%)$ had been diagnosed with diabetes, and $32(25.4 \%)$ had 
been diagnosed with hypertension. A total of 43 (34.1\%) had been told they had high blood cholesterol, $54(42.9 \%)$ had a family history of diabetes, and 94 (74.6\%) had the last regular medical check-up within the past year. Similarly, $53(42.1 \%)$ had only 1-2 days per week of moderate physical activities, $52(41.3 \%)$ had only 1-2 days per week of vigorous physical activities, $8(6.3 \%)$ had a history of smoking, and $74(58.7 \%)$ were very careful or somewhat careful in selecting healthier diet. Distribution of sociodemographic and clinical characteristics of the study participants are presented in Table 1.

Table 2 shows significant differences between males and females for age $(\mathrm{M}=45.2 ; \mathrm{SD}=47.9$ for males, and $M=47.9 ; S D=15.2$ for females, $p=.31)$, weight $(M=81.4 ; S D=17.6$ for males, and $\mathrm{M}=77.2 ; \mathrm{SD}=16.5$ for females, $\mathrm{p}=<.0001), \mathrm{BMI}(\mathrm{M}=27.5 ; \mathrm{SD}=5.5$ for males, and $\mathrm{M}=29.7 ; \mathrm{SD}$ $=5.8$ for females, $\mathrm{p}=.041)$, and $\mathrm{HbA}_{1} \mathrm{c}(\mathrm{M}=6.1 ; \mathrm{SD}=1.2$ for males, and $\mathrm{M}=5.8 ; \mathrm{SD}=.84$ for females, $\mathrm{p}=.21$ )

The BMI was used as an objective measure of whether participants were normal weight, overweight, or obese. The mean BMI of the study sample was 28.8 (considered overweight), with $73.8 \%$ of the sample classified as overweight or obese and $68.0 \%$ of male participants and $77.6 \%$ of female participants falling under this classification. Only $26.2 \%$ of the sample was classified to be at a healthy BMI $\left(<25 \mathrm{~kg} / \mathrm{m}^{2}\right)$. There were differences in BMI category for males and females $(\mathrm{p}=.02)$, and category of $\mathrm{HbA}_{1} \mathrm{c}(\mathrm{p}=.62)$, Table 3 .

\section{Prevalence of diagnosed and undiagnosed pre-diabetes and diabetes}

Table 4 summarizes the prevalence of diagnosed and undiagnosed pre-diabetes and diabetes. A total of $36(28.6 \%)$ participants had pre-diabetes $\left(\mathrm{HbA}_{1 \mathrm{c}}\right.$ of $\left.5.7-6.4 \%\right)$, of whom $12(9.5 \%)$ were new (unaware) cases and 24 (19.1\%) were previously diagnosed (aware) cases of pre-diabetes. A total of 32 (25.4\%) participants were found to have diabetes as defined by $\mathrm{HbA}_{1 \mathrm{c}}$. Thus, the prevalence of diabetes in the whole sample was $25.4 \%$, comprising $5.6 \%$ new (unaware) cases and $19.8 \%$ previously 
diagnosed (aware) cases of diabetes.

\section{Risk factors for diabetes}

The association between socio-demographic and clinical characteristics of study participants and glycemic level is presented in Table 5. Pre-diabetes and diabetes were more prevalent among participants between ages 36-60 years $(n=23,63.9 \%$ and $n=15,50.0 \%$, respectively, $p=.08)$, those who were married $(\mathrm{n}=28,77.8 \%$ and $\mathrm{n}=13,43.3 \%$ respectively, $\mathrm{p}=.001)$. Similarly, significant associations were found with pre-diabetes and diabetes among those with previously diagnosed hypertension $(n=8,22.2 \%$ and $n=14,46.7 \%$ respectively, $p=.008)$, those with previously diagnosed high blood cholesterol $(\mathrm{n}=8,22.2 \%$ and $\mathrm{n}=24,80.0 \%, \mathrm{p}<.0001)$, and those who had $\leq 2$ days per week of moderate physical activities $(\mathrm{p}=.02)$.

\section{Treatment and control status of diabetes}

All 25 participants with previously diagnosed diabetes reported being on treatment (oral antihypoglycemic medications or insulin). Among all 25 participants who had been told they had diabetes or were already on treatment, only $5(20.0 \%)$ had a good glycemic control status whereas the rest (80.0\%) had a poor glycemic control signifying $\mathrm{HbA}_{1 \mathrm{c}}$ above $7 \%$ (Table 6).

\section{Discussion}

This study aimed to assess the prevalence of diabetes and associated risk factors in the African immigrant population in Sacramento County, California. Overall prevalence of pre-diabetes and diabetes among the study participants was $28.6 \%$ and $25.4 \%$ respectively. Our findings have confirmed the high prevalence of pre-diabetes and diabetes among African immigrant populations in Sacramento County, highlighting the critical need for both early detection of the disease and prevention measures. ${ }^{25,26}$ Indeed, while almost 1 in 5 participants in the study had prevalent diabetes, $21.9 \%$ of 
those with the disease were discovered only during the time of data collection. These findings are consistent with some prior studies showing that African immigrants had a higher prevalence of diabetes (PR: $1.41[95 \% \mathrm{CI}, 1.01-1.96])^{27}$ and African immigrant patients have a high prevalence of pre-diabetes and diabetes compared to U.S.-born patients. ${ }^{28}$ In Minnesota, Njeru et $a^{28}$ found the prevalence of diabetes was significantly higher among Somali versus non-Somali patients ( $12.1 \mathrm{vs} 5.3 \%$; $p=0.0001$ ), as was prediabetes $(21.3 \mathrm{vs} 17.2 \% ; p<0.02)$. Ukegbu et al ${ }^{29}$ found a similar metabolic risk and metabolic syndrome prevalence in Africans and African Americans (10 vs. 13\%, P = 0.74), but a higher prevalence of hypertension, glycemia (fasting and 2-hour glucose), and visceral adipose tissue in African immigrants. The Minnesota Department of Human Services also found that $29 \%$ of Somali immigrant elders and $18.3 \%$ of Oromo (an ethnic group inhabiting Ethiopia, Kenya, and Somalia) immigrant elders had diabetes. ${ }^{30}$ This observation may be explained by the accelerated changes in dietary and lifestyle patterns (especially physical inactivity) contributing to the increased prevalence of not only diabetes, but also, obesity, hypertension, and hypercholesterolemia in African immigrant populations

In the present study, $73.8 \%$ of the participants were overweight or obese (mean BMI of 28.8), with female compared to male participants being more overweight or obese ( $77.6 \%$ vs $68.0 \%)$. This is consistent with a study in Minnesota that found the prevalence of obesity to be significantly higher among Somali versus non-Somali patients (34.6 vs $32.1 \%$; $p=0.047$ ). ${ }^{28}$ This is also consistent with some studies that have shown that about $35 \%$ of adults older than 18 years of age were obese in the U.S., with the highest prevalence identified in the non-Hispanic black population (48 \%), followed closely by the Hispanic population (43\%), non-Hispanic white population (33\%), and non-Hispanic Asian population $(11 \%) \cdot{ }^{31}$ Another study has shown that female immigrants to the United States had a $10 \%$ increased likelihood of being obese at the point of migration than native-born counterparts. ${ }^{32}$ This 
is also in line with prior studies, one study with a sample of 208 Somali immigrants in Oslo, Norway which found that $104(50 \%)$ participants were either overweight $(35 \%)$ or obese $(15 \%)$, with approximately $64 \%$ of overweight participants being women ${ }^{33}$ and another study in New Zealand which found that $71 \%$ of Somali women had a BMI $\geq 25 \mathrm{~kg} / \mathrm{m} 2 .{ }^{34}$ As such, these findings are not unexpected due to evidence showing that immigrants from low or medium income countries to high income countries have increased susceptibility to obesity compared to their counterparts in their native countries. ${ }^{35}$ The highest prevalence of overweight and obesity in African immigrant females could be related to cultural values, as African populations prefer larger body size women as a sign of fertility, healthiness or happiness. ${ }^{36,37,38}$

Only $19.8 \%$ of all cases of diabetes were previously known cases or on treatment, among whom only about one-fifth had controlled blood glucose status $\left(\mathrm{HbA}_{1} \mathrm{c}\right.$ below 7\%). Our findings support those of a previous study in the Primary Care Internal Medicine and Family Medicine clinics at Mayo Clinic Rochester, MN from April 1, 2008 to June 30, 2008 that found Somali patients with diabetes were less likely to meet the criteria for optimal glycemic control $\left(\mathrm{HbA}_{1} \mathrm{c}<7 \%\right)$ than non-Somali patients. ${ }^{39}$ Another study conducted among hospitalized diabetic patients in France, found that African immigrant patients had higher rates of $\mathrm{HbA}_{1} \mathrm{c}$ and less self-reported adherence compared with other patients. ${ }^{40}$ These studies suggest that glycemic control is poorer in African immigrants than in their non-African counterparts in the U.S. and France.

About $21.4 \%$ of participants with pre-diabetes and $5.6 \%$ of participants with diabetes were previously undiagnosed. This is consistent with a cross-sectional study accessing baseline data from 2,856 adults recruited to the Cameron County Hispanic Cohort (CCHC) in Brownsville, Texas between 2004 and 2014, aged 18 years and older that found that 40\% of those with diabetes (345 participants) were previously undiagnosed. ${ }^{41}$ Another study in the state of Punjab, India has shown that among all 
persons with diabetes, only $37(18 \%)$ were known case of DM or on treatment whereas the rest were previously undiagnosed. ${ }^{42}$ These results suggest early identification and therapy of individuals with undiagnosed cases of diabetes and ensuring regular follow up to avoid microvascular as well as macrovascular complications. ${ }^{42}$

In the present study, age group of 36-60 years, being married, being employed full-time, hypertension, high blood cholesterol $8(22.2 \%)$ and $24(80.0 \%)$, and 0-2 days per week of moderate physical activities were the major variables associated with diabetes. These findings support those of the Health Survey for England [HSE], ${ }^{43}$ that the prevalence rates of type 2 diabetes were $16.2 \%$ and $6 \%$ in African immigrant men and women aged $\geq 35$ years compared with $5.1 \%$ and $2.4 \%$ in English general population men and women, respectively. These findings also support prior findings that the risk for type 2 diabetes among Somali immigrant women increases with increased age, with the mean age of 35.7 years among those with a low risk of diabetes, the mean age of 37 years among those with moderate risk of diabetes, and the mean age of 38.3 years among those at high risk for diabetes. ${ }^{44}$ In addition, Gele et $\mathrm{al}^{44}$ found that the likelihood of getting type 2 diabetes among Somali immigrant women was significantly associated with having hypertension (OR: 7.32, 95\% CI: 1.95-27.5) and the group with no rigorous physical activity was two times as likely as their counterparts practicing physical activity up to five hours a week to be at risk for type 2 diabetes (OR: $2.34,95 \%$ CI: 1.00 5.50), an association that turned out to be significant after it was adjusted for age.

Our findings support DesMeules et al's ${ }^{45}$ conclusion that there is an increased risk for developing type 2 diabetes and associated complications after African immigrants have lived in the U.S. for three years or more and the conclusion from the Mayo Clinic that African immigrants are more likely to develop diabetes compared to U.S.-born citizens, and have higher chances of experiencing complications of diabetes such as heart or kidney disease and stroke. ${ }^{46}$ 


\section{Strengths and limitations}

The distinctive strengths of the present study are the data collection by the author (DMK) and diagnosis of diabetes was based on measurement of $\mathrm{HbA}_{1 \mathrm{c}}$, which is the pre-diabetes and diabetes diagnostic criteria recommended by the $\mathrm{ADA}^{23}$ and the gold-standard marker to assess the control of diabetes. Measurements of weight and height to calculate the BMI, blood presure, and $\mathrm{HbA}_{1 \mathrm{c}}$ in this study not only constitute a reliable source of information, but also increase the trustworthiness of collected information. Also, the present study included participants older than 65 years, a proportion of individuals whose diabetes prevalence is likely to be particularly high. ${ }^{47,48}$ The important limitations of the present study are its cross-sectional design, hence making it difficult to draw causal inferences and its small sample size which may not be representative.

\section{Implications for Practice and Research}

Our study provided the first and reliable epidemiological data regarding the high burden of diabetes among African immigrants in Sacramento county. African immigrants are found to have a high prevalence of pre-diabetes, diabetes, and multiple risk factors of diabetes, and a poor glycemic control among those with diabetes, calling for immediate attention. This study also highlights a significant burden of undiagnosed cases of pre-diabetes and diabetes in the African immigrant population, which will not only generate increased diabetes care costs within the next decade, but also reduce the quality and duration of life in this population. There is a need to identify the large pool of undiagnosed cases of pre-diabetes and diabetes and provide early opportunity to make important lifestyle changes and treatment in order not only to prevent or delay the progression towards type 2 diabetes, but also to avoid its associated complications. Thus, the initiation of culturally sensitive lifestyle interventions which include change in diet, exercise, and education may have a substantial ameliorating impact on prevention of risk factors associated with type 2 diabetes and its complications. 


\section{References}

1. World Health Organization Global Report on Diabetes. WHO Press, World Health Organization, 20 Avenue Appia, 1211 Geneva 27, Switzerland; 2016.

2. Gilmer TP, O'Connor PJ. The Growing Importance of Diabetes Screening. Diabetes Care. 2010;3(7):1695-1697.

3. California Diabetes Program-2012. California Diabetes Fact Sheet, Technical Notes. www.caldiabetes.org. Accessed October 20, 2018.

4. Kirtland KA, Li YF, Geiss LS, Thompson TJ. State-specific incidence of diabetes among adults --- Participating states, 1995-1997 and 2005-2007. MMWR. 2008;57(43):1169-1173.

5. He G, Schillinger D. Disparities in prediabetes: prevalence, awareness, and behavior. Poster presentation at UCSF Disparity Research Symposium II; San Francisco, CA; 2008.

6. Kindarara DM, McEwen MM, Crist JD, Loescher LJ. Health-Illness Transition Experiences with Type 2 Diabetes Self-management of Sub-Saharan African Immigrants in the United States. The Diabetes Educator. 2017;43(5):506-518

7. Anderson M. African immigrant population in U.S. steadily climbs. Pew Research Center; 2017. http://www.pewresearch.org/fact-tank/2017/02/14/african-immigrant-population-in-u-s-steadilyclimbs/. Accessed October 20, 2018.

8. Read JG, Emerson MO, Tarlov A. Implications of black immigrant health for U.S. racial disparities in health. $J$ Immigr Health. 2005;7(3):205-12.

9. Shepard RM. Cultural Adaptation of Somali Refugee Youth. New York: LFB Scholarly Publishing LLC; 2008. 
10. McGuigan CL. Diabetes in the Eritrean and Ethiopian community: cultural information and recommendations for diabetes educators. http://ethnomed.org/clinical/diabetes/diabetes-in-theeritreanand-ethiopian-community-cultural-information-and-recommendations-for-diabetes-educators. Accessed October 20, 2018.

11. Sewali B, Harcourt N, Everson-Rose SA, et al.. Prevalence of cardiovascular risk factors across six African Immigrant Groups in Minnesota. BMC Public Health. 2015;15(411):1-7.

12. Owens CW, Piccinin D, Lai, K, et al. Diabetes in the Somali Community: Cultural Information and Recommendations for Diabetes Educators. EthnoMed. 2002.

http://ethnomed.org/clinical/diabetes/diabetes-in-the-somali-community-cultural-information-andrecommendations-for-diabetes-educators. Accessed October 20, 2018.

13. Associate Press. Somali Immigrants Suffering a Peril of Plenty: Diabetes. 2002. Retrieved from http://www.highbeam.com/doc/1P1-52760040.html. Accessed October 20, 2018.

14. Centers for Disease Control and Prevention.The Social-Ecological Model: A Framework for Prevention. 2018. https://www.cdc.gov/violenceprevention/overview/social-ecologicalmodel.html. Accessed October 20, 2018

15. Gary-Webb TL, Suglia SF, Tehranifar P. Social Epidemiology of Diabetes and Associated Conditions. Curr Diab Rep. 2013;13(6):850-859.

16. American Diabetes Association. Screening for pre-diabetes and diabetes in undiagnosed adults. Diabetes Care. 2011;34(Supp1 1):S13.

17. American Community Survey. Sub-Saharan African-born immigrants. http://immigrationpolicy.org/sites/default/files/docs/afri can_fact_sheet.pdf. Accessed October 20, 2018. 
18. Zheng H, Pry J, Chung H, Lockett C, Kasirye OC. A Description of the Health Status and Mortality Experience of Sacramento County Residents. Community Health Status Report - 2014. http://www.dhhs.saccounty.net/PUB/Documents/Disease-Control-Epidemiology/RTHealthStatusReport2014Final.pdf. Accessed October 20, 2018.

19. WHO Expert Consultation. Appropriate body-mass index for Asian populations and its implications for policy and intervention strategies. Lancet. 2004;363:157-163.

20. Kilpatrick ES, Atkin SL. Using hemoglobin $\mathrm{A}_{1 \mathrm{c}}$ to diagnose type 2 diabetes or to identify people at high risk of diabetes. BMJ. 2014;348:g2867.

21. American Diabetes Association. Standards of medical care in diabetes-2012. Diabetes Care. 2012;35(Supp1 1):S11-S63.

22. Rowan CP, Miadovnik LA, Riddell MC, Rotondi MA, Gledhill N, Jamnik VK. Identifying persons at risk for developing type 2 diabetes in a concentrated population of high risk ethnicities in Canada using a risk assessment questionnaire and point-of-care capillary blood $\mathrm{HbA} 1 \mathrm{c}$ measurement. $B M C$ Public Health. 2014;14929.

23. James PA, Oparil S, Carter BL, et al. evidence-based guideline for the management of high blood pressure in adults: report from the panel members appointed to the Eighth Joint National Committee (JNC 8). JAMA. 2014;311(5):507-20.

24. American Diabetes Association. Diagnosis and classification of diabetes mellitus. Diabetes Care. 2012;35(Suppl 1):S64-S71.

25. Venters H, Gany F. African immigrant health. J Immigr Minor Health. 2011;13(2):333-344.

26. American Diabetes Association. Screening for Diabetes. Diabetes Care. 2002;25(suppl 1):s21-s24.

27. Commodore-Mensah Y, Selvin E, Aboagye J. et al. Hypertension, overweight/obesity, and diabetes 
among immigrants in the United States: an analysis of the 2010-2016 National Health Interview Survey. BMC Public Health. 2018;18:773.

28. Njeru JW, Tan EM, St. Sauver J. et al. High Rates of Diabetes Mellitus, Pre-diabetes and Obesity Among Somali Immigrants and Refugees in Minnesota: A Retrospective Chart Review. J Immigrant Minority Health. 2016;18(1343).

29. Ukegbu UJ, Castillo DC, Knight MG. Et al. Metabolic syndrome does not detect metabolic risk in African men living in the U.S. Diabetes Care. 2011;34(10):2297-229

30. Metropolitan Area Agency on Aging. Demographic and service data on Oromo elders. http://www.tcaging.org/downloads/2010o.pdf. Accessed October 20, 2018.

31. Centers for Disease Control and Prevention. Adult obesity facts. 2014. http://www.cdc.gov/obesity/data/adult.html. Accessed October 20, 2018.

32. Averett SL, Argys LM, Kohn JL. Immigration, obesity and labor market outcomes in the UK. 2012. http://ftp.iza.org/dp6454.pdf. Accessed October 20, 2018.

33. Gele AA, Mbalilaki AJ. Overweight and obesity among African immigrants in Oslo. BMC Research Notes. 2013;6:119.

34. Guerin PB, Elmi FH, Corrigan C. Body composition and cardiorespiratory fitness among refugee Somali women living in New Zealand. J Immigr Minor Health. 2007;9(3):191-196.

35. Delavari M, Sønderlund A, Swinburn B, Mellor D, Renzaho A. Acculturation and obesity among migrant populations in high income countries - a systematic review. BMC Public Health. $2013 ; 13: 458-60$.

36. Levitt NS. Diabetes in Africa: epidemiology, management and healthcare challenges. Heart. 2008;94:1376-1382. 
37. Tuei VC, Maiyoh GK, Ha C-E. Type 2 diabetes mellitus and obesity in SubSaharan Africa. Diabetes Metabolism Research and Reviews. 2010. doi: 10.1002/dmrr.1106.

38. Renzaho AM: Fat, rich and beautiful: changing socio-cultural paradigms associated with obesity risk, nutritional status and refugee children from sub-Saharan Africa. Health Place. 2004;10(1):105113.

39. Wieland ML, Morrison TB, Cha SS, Rahman AS, Chaudhry R. Diabetes Care Among Somali Immigrants and Refugees. J Community Health. 2012;37:680-684.

40. Obadia G, Lombrail P, Thibult N, Eschwege E, Passa P. Hospital care of insulin-treated diabetes in African immigrants, in France. Diabetes Metab. 1986;12(1):16-20.

41. Fisher-Hoch SP, Vatcheva KP, Rahbar MH, McCormick JB. Undiagnosed Diabetes and PreDiabetes in Health Disparities. PLoS ONE. 2015;10(7):e0133135.

42. Tripathy JP, Thakur JS, Jeet G. et al. Prevalence and risk factors of diabetes in a large communitybased study in North India: results from a STEPS survey in Punjab, India. Diabetology Metabolic Syndrome. 2017;9(8).

43. Health Survey for England. (HSE-2004): Health of Ethnic Minorities. 2004. http://www.ic.nhs.uk/webfiles/publications/hlthsvyeng2004ethnic/HealthSurveyForEngland161205_P DF\%20.pdf. Accessed on October 20, 2018.

44. Gele AA, Pettersen KS, Kumar B, Torheim LE. Diabetes Risk by Length of Residence among Somali Women in Oslo Area. Journal of Diabetes Research. 2016; Article ID 5423405:10 pages. 45. DesMeules M, Gold J, McDermott S. et al. Disparities in mortality patterns among Canadian immigrants and refugees, 1980-1998: results of a national cohort study. Journal of Immigrant and Minority Health. 2005; 7(4):221-232. 
46. Lynk M. Diagnosing Ways to Reduce Diabetes and Chronic Diseases in an Era of Reform. Center on Health Disparities at the Adventist HealthCare. Retrieved from http://northpotomac.patch.com/blog_posts/diagnosing-ways-to-reduce-diabetes-and-chronic-diseasesin-an-era-of-reform. Accessed on October 20, 2018.

47. Wild S, Roglic G, Green A, Sicree R, King H. Global prevelence of diabetes: Estimates for the year 2000 and projections for 2030. Diabetes care. 2004;27(5):1047-1053.

48. Qiao Q, Hu G, Tuomilehto J. et al. Age- and sex-specific prevalence of diabetes and impaired glucose regulation in 11 Asian cohorts. Diabetes Care. 2003;26:1770-80. 